Интернет-журнал «Транспортные сооружения» https://t-s.today

Russian journal of transport engineering

2018, №2, Том 5 / 2018, No 2, Vol 5 https://t-s.today/issue-2-2018.html

URL статьи: https://t-s.today/PDF/07SATS218.pdf

DOI: 10.15862/07SATS218 (http://dx.doi.org/10.15862/07SATS218)

Статья поступила в редакцию 14.04.2018; опубликована 08.06.2018

Ссылка для цитирования этой статьи:

Евстратов Н.П. Особенности создания придорожных насаждений // Интернет-журнал «Транспортные сооружения», 2018 №2, https://t-s.today/PDF/07SATS218.pdf (доступ свободный). Загл. с экрана. Яз. рус., англ. DOI: $10.15862 / 07$ SATS218

For citation:

Evstratov N.P. (2018). Especially in the creation of roadside plantations. Russian journal of transport engineering, [online] 2(5). Available at: https://t-s.today/PDF/07SATS218.pdf (in Russian). DOI: 10.15862/07SATS218

\title{
УДК 625.77:630*266
}

\section{Евстратов Николай Петрович}

ФГБОУ «Брянский государственный инженерно-технологический университет», Брянск, Россия

Доцент, кандидат сельскохозяйственных наук E-mail: evstratov.bryansk@gmail.com

\section{Особенности создания придорожных насаждений}

Аннотация. Автомобильные дороги должны вписываться в ландшафт таким образом, чтобы их отрицательное влияние на внешний вид и состояние природного ландшафта было минимальным. Подобное вмешательство в природу приводит к расчленению лесных массивов, нарушению естественного движения грунтовых вод, стока поверхностных вод, разрушению мест обитания и отсечение путей миграции животных, ухудшению климата.

Исключить отрицательные воздействия вряд ли удается полностью, за счет выбора трассы с учетом условий местности и с помощью соответственного оформления дорога иногда может вписаться в ландшафт и, может быть, даже улучшить его внешний вид. Кроме этого, при дорожном строительстве можно создать интересные и полноценные места обитания животных и растений, увеличивая таким образом биоразнообразие придорожных ландшафтов.

Закладка придорожных ландшафтов выходит далеко за пределы обычного окаймления дороги рядами насаждений. Надлежащее размещение придорожной растительности газонов, деревьев и кустарников, обеспечивает значительное сокращение затрат на уход и поддержание в порядке полотна дороги.

Известно, что эксплуатация дорожных магистралей приводит к техногенному загрязнению прилегающих территорий вместе с придорожными насаждениями. Кроме этого, дорожные магистрали могут проходить по загрязненной радионуклидами территории. В этом случае часто происходит явление синергизма, когда техногенные загрязнения суммируются с радиационным фактором. При этом суммарное влияние двух факторов на биологические объекты значительно возрастает.

Основным показателем радиационной обстановки на объектах исследований (стационарные объекты, в виде пробных площадей) принималась мощность поглощённой дозы (МПД). Измерения проводились ежегодно осенью при проведении перечета деревьев. В этих


прибор АИ - 1024-95-17. 
Для изучения влияния ионизирующих излучений на появление аберраций хромосом был проведен цитологический анализ митозов в корешках проростков сосны, ели и дуба. Выход разного типа хромосомных аберраций в клетках растений используется в качестве показателя, характеризующего цитогенетические повреждения при радиационном облучении. Частое использование корней для изучения роста и деления клеток обусловлено относительной простотой и четкостью их анатомического строения, более резким, чем в стебле, разделением меристемы и зоны растяжения по длине корня, наличием большого числа митозов в меристеме нормально растущего корня, стабильностью роста корня и легкостью обработки корней различными веществами. Учет нарушений хромосом велся в анафазе и начальной телофазе на давленых препаратах.

Ключевые слова: ландшафт; загрязнение; радионуклиды; поллютанты; синергизм; ядро; цитокенез; анафаза; мосты; фрагменты; хромосомы; митоз; амитоз; меристема; ген; грей; беккерель; рДНК

\section{Введение}

При включении дороги в ландшафт предусматривается комплекс природоохранных мероприятий, который включает: выбор трассы дороги; формирование рельефа местности, обустройство склонов придорожных насыпей; сохранение растительности; закладка новых насаждений; компенсационно-восстановительные работы.

Для нас большое значение имеет закладка новых насаждений, которые обеспечивают безопасную эксплуатацию дороги, создают систему ориентиров вдоль дороги, защищают от ослепления и ветра.

Придорожные насаждения обеспечивают надежность дорожных сооружений, защищают почвы от эрозии, способствуют укреплению насыпей. Кроме этого увязывают дорожные сооружения с окружающим пространством, защищают прилегающую среду от транспортных выбросов.

К таким посадкам следует отнести ветрозащитные насаждения, снегозащитные насаждения и насаждения, обеспечивающие защиту водителей от ослепления. При создании этих насаждений следует, что это в большинстве случаев аллейные многорядные посадки. Видовой состав придорожной полосы должен соответствовать составу придорожных насаждений, создание которых целесообразно производить крупномерными саженцами древесных пород и кустарников.

При создании придорожных насаждений из местных видов следует учитывать, что семена, полученные в радиационно-загрязненных насаждениях, могут иметь определенные отклонения, которые были нами выявлены в предварительных исследованиях.

Древесные и кустарниковые виды растений оказались наиболее радиочувствительными. Некоторые ученые объясняют это тем, что данные виды растений более примитивны в сравнении с травянистыми. Наиболее радиочувствительными из хвойных видов являются сосна обыкновенная и ель европейская.

Радиочувствительность семян отражает филогенетическое положение растения: для цветковых более древние примитивные виды отличаются повышенной радиочувствительностью семян в сравнении с более молодыми в филогенетическом отношении формами [16]. 
Исследования летальной дозы семян древесных растений позволили составить следующий ряд радиорезистентности. Ель обыкновенная, пихта сибирская, сосна обыкновенная, береза повислая, липа мелколистная [11].

В качестве критериев радиационного повреждения обычно принимаются частота хромосомных аберраций, изменения в репродуктивных тканях и ухудшения качества семян [22]. У сосны обыкновенной при дозе 1200 рад рост хромосомных аберраций доходит до $3.5 \%$. Доминирующими являются нарушения хроматидного типа [5].

В настоящее время выдвинута концепция, что при ежегодном хроническом облучении с дозой 5 Гр каких-либо отклонений в функционировании даже самых радиочувствительных экосистем не происходит.

При высоких дозах облучения к концу вегетации отношение частот хроматидных аберраций к хромосомным увеличилось, при этом значительно возросла частота фрагментов: до 50 \% по сравнению с другими типами нарушений [4]. При сублетальных дозах хромосомные аберрации в клетках хвои возникают как в год облучения, так и в последующие 2 года, т. е. имеют продленный характер [19].

Радиационные эффекты наблюдались в относительно ближней зоне аварии на ЧАЭС при сравнительно высоких мощностях дозы радиоактивного облучения $[1,7]$. Видимыми в микроскоп нарушениями для растений оказались аберрации хромосом; их увеличение статистически достоверно и наблюдалось на значительном удалении от источника аварии [8, 24].

Спектр аберраций у сосны в митозе представлен хромосомными и хромотидными мостами, микрофрагментами. Уровень индуцированных аберраций был практически одинаков на протяжении 5 лет, хотя поглощаемая доза снизилась в 5-10 раз [19, 21].

Дозы радиации меньше 0,01 Гр/сутки считаются малыми [9]. А.М. Кузин [12] к ним относит дозы, превышающие природный радиационный фон на порядок и выше и лежащие на два порядка ниже ЛД5о для данного вида. При таких дозах нарушение жизнедеятельности организмов не происходит. Минимальная мощность дозы, которая вызывает после нескольких лет облучения изменения в семеобразовании и скорости роста, равна 0,02 Гр/сутки или 7,3 Гр/год, а максимально безопасная - 0,002 Гр/сутки или 0,73 Гр/год, облучение в этой дозе не вызвало соматических нарушений [3].

С увеличением дозы облучения частота всех типов мутаций превысила соответственно их уровень в контроле [9].

\section{Методы}

Основным показателем радиационной обстановки на объектах исследований (стационарные объекты, в виде пробных площадей) принималась мощность поглощённой дозы (МПД). Измерения проводились ежегодно осенью при проведении перечета деревьев. В этих же точках отбирались пробы грунта с определением плотности загрязнения в Бк/м², применяя прибор АИ - 1024-95-17.

Для изучения влияния ионизирующих излучений на появление аберраций хромосом был проведен цитологический анализ митозов в корешках проростков сосны, ели и дуба. Выход разного типа хромосомных аберраций в клетках растений используется в качестве показателя, характеризующего цитогенетические повреждения при радиационном облучении [3]. Частое использование корней для изучения роста и деления клеток обусловлено относительной простотой и четкостью их анатомического строения, более резким, чем в стебле, разделением 
меристемы и зоны растяжения по длине корня, наличием большого числа митозов в меристеме нормально растущего корня, стабильностью роста корня и легкостью обработки корней различными веществами [6]. Учет нарушений хромосом велся в анафазе и начальной телофазе на давленых препаратах [17].

Как известно [23], митотическая активность клеток тесно связана с ростом растений, а последний обычно коррелирует с частотой перестроек хромосом. Окрашивание корешков проростков проводили ацетокармином.

Цитологические препараты готовились в хлоралгидрате. Корешок помещался на предметное стекло, лезвием безопасной бритвы отрезался самый его кончик (1-1,5мм) и оставлялся на предметном стекле в двух каплях хлоралгидрата, накрывался сверху покровным стеклом и фильтрованной бумагой, а затем раздавливался круговым движением ногтя, карандаша, препаровальной иглы.

Желуди дуба проращивались в ящиках с влажным песком. Корешки проростков желудей, достигшие 0,5-1,5 cм, фиксировали в уксусном алкоголе (1:3), хранили проростки в 70 \% этиловом спирте в холодильнике.

Перед окрашиванием корешки выдерживали в 50 \% НCI для мацерации в течение 5-10 мин без подогрева, потом 2-3 раза промывали в дистиллированной воде и ополаскивали в $45 \%$ уксусной кислоте.

Препараты окрашивались в ацетокармине путем 2-3 кратного доведения раствора до легкого кипения. Для усиления окрашивания корешки оставляли на ночь в том же растворе. После окрашивания проводили одновременную мацерацию и дифференциацию объекта, помещая материал на предметное стекло в каплю смеси 80 \% хлоралгидрата и 45 \% уксусной кислоты (1:1), выдерживая его в этой смеси от 5 до 20 минут [2].

Приготовленные таким образом препараты просматривались под микроскопом МБИ-6 с увеличением $40 \times 7 \times 2,5$ и $40 \times 10 \times 2,5$.

При просмотре учитывались нарушения в анафазе митоза с учетом МПД излучения и плотности загрязнения.

На временных препаратах определялось общее число просмотренных клеток, количество делящихся клеток, общее количество клеток с анафазами, количество анафаз с нарушениями и их типы по Е.Н. Самошкину [18] и В.П. Сидорову [20]: хромосомные аберрации (мосты и фрагменты) и нарушения клеточных делений (выход хромосом вперед, отставание, одновременно выход и оставление хромосом, другие комплексные нарушения).

Вычислялись митотический индекс и относительная продолжительность анафазы. Митотический индекс определялся как количество делящихся клеток (\%) от их общего числа.

\section{Результаты}

Частота хромосомных аберраций исследовалась у древесных видов претендующих на роль основных деревьев в аллейных посадках вдоль автомобильных дорог. К таким видам относятся сосна обыкновенная, ель европейская и дуб черешчатый. Хвойные виды древесных растений привлекательны тем, что остаются зелеными в течение всего года, а дуб черешчатый выгодно отличается своей долговечностью. Следует отметить также, что травянистая и кустарниковая растительность наиболее устойчива в условиях радиоактивного загрязнения $\mathrm{C}_{\mathrm{s}}$ - 137 (радиоцезием), а наименее устойчивы хвойные виды. 
Таблица 1

Частота хромосомных аберраций проростков семян сосны обыкновенной

\begin{tabular}{|c|c|c|c|c|c|c|}
\hline \multirow{4}{*}{$\begin{array}{c}\text { Митотический } \\
\text { индекс, \% }\end{array}$} & \multirow{4}{*}{$\begin{array}{c}\text { Продолжительность } \\
\text { анафазы, \% }\end{array}$} & \multicolumn{5}{|c|}{ Количество анафаз с нарушениями, \% } \\
\hline & & \multirow{3}{*}{ Всего } & \multicolumn{3}{|c|}{ Хромосомные аберрации } & \multirow{3}{*}{$\begin{array}{c}\text { Выходы и } \\
\text { отставания } \\
\text { хромосом }\end{array}$} \\
\hline & & & \multirow{2}{*}{$\begin{array}{l}\text { Общее } \\
\text { число }\end{array}$} & \multicolumn{2}{|c|}{ В том числе } & \\
\hline & & & & Мосты & Фрагменты & \\
\hline \multicolumn{7}{|c|}{ КОНТРОЛЬ } \\
\hline 9,73 & 17,22 & 14,88 & 2,18 & 0,58 & 1,60 & 12,70 \\
\hline \multicolumn{7}{|c|}{$148 * 10^{4}-296 * 10^{4}$ БК/ $/ \mathrm{m}^{2}\left(40-80 \mathrm{Ku} / \mathrm{KM}^{2}\right)$} \\
\hline 8,69 & 18,57 & 26,76 & 2,32 & 0,78 & 1,54 & 24,4 \\
\hline \multicolumn{7}{|c|}{$296 * 10^{4}-1184 * 10^{4}$ БК/ $/ \mathrm{M}^{2}\left(80-320 \mathrm{Ku} / \mathrm{KM}^{2}\right)$} \\
\hline 8,05 & 18,76 & 32,07 & 2,99 & 0,76 & 2,23 & 29,08 \\
\hline
\end{tabular}

У сосны обыкновенной митотический индекс незначительно уменьшается на 1-1,2 \% по сравнению с контролем. Повышение уровня радиации снижает митотический индекс всего на 0,2 \%, практически он остается почти на одном уровне (таблица 1 ).

Продолжительность анафазы незначительно возрастает на 1,4-1,5 \%. Повышение уровня радиации оставляет продолжительность анафазы на одном уровне, так как увеличение признака составляет всего 0,19\%.

Значительно возрастает под влиянием радиации количество анафаз с нарушениями, хотя и в контроле этот показатель составляет 14,88 \%. Превышение по сравнению с контролем составляет 11,9-17,19 \%, по мере усиления радиации количество анафаз с нарушениями тоже возрастает на 5,3\%. Однако следует отметить, что наибольший вклад в этот показатель вносят такие нарушения, как выходы и отставания хромосом в веретене деления клетки. Выходы и отставания хромосом наблюдаются и в проростках семян из контрольного насаждения на уровне 12,7 \%. В проростках семян загрязненных сосняков, показатель возрастает на $11,7-16,4 \%$, повышение радиации дает рост анафаз с выходом и отставанием хромосом на $4,7 \%$.

Общее число хромосомных аберраций в контрольном насаждении составляет 2,18 \%. С повышением радиации показатель возрастает на 0,14-0,81 \%, достигая уровня 2,99 \%.

Большая часть хромосомных аберраций приходится на такие виды как фрагменты. Причем в проростках семян из контрольных насаждений и при первом пороге повышения радиации их количество составляет 1,6-1,54 \%, то есть практически равно. Увеличение радиации незначительно повышает число фрагментов на 0,8 \% и составляет $2,23 \%$. Количество мостов повышается всего на 0,2 \% по сравнению с контролем соответственно 0,58-0,78\%. Дальнейшее усиление радиационного фактора почти не влияет на данный показатель. Он составляет $0,76 \%$.

Таблица 2

Частота хромосомных аберраций проростков семян ели европейской

\begin{tabular}{|c|c|c|c|c|c|c|}
\hline \multirow{4}{*}{$\begin{array}{c}\text { Митотический } \\
\text { индекс, \% }\end{array}$} & \multirow{4}{*}{$\begin{array}{c}\text { Продолжительность } \\
\text { анафазы, \% }\end{array}$} & \multicolumn{5}{|c|}{ Количество анафаз с нарушениями, \% } \\
\hline & & \multirow{3}{*}{ Всего } & \multicolumn{3}{|c|}{ Хромосомные аберрации } & \multirow{3}{*}{$\begin{array}{c}\text { Выходы и } \\
\text { отставания } \\
\text { хромосом }\end{array}$} \\
\hline & & & \multirow{2}{*}{$\begin{array}{l}\text { Общее } \\
\text { число }\end{array}$} & \multicolumn{2}{|c|}{ В том числе } & \\
\hline & & & & Мосты & Фрагменты & \\
\hline \multicolumn{7}{|c|}{ КОНТРОЛЬ } \\
\hline 9,52 & 15,57 & 16,55 & 2,25 & 0,81 & 1,44 & 14,30 \\
\hline \multicolumn{7}{|c|}{$148 * 10^{4}-296 * 10^{4}$ Бк/м ${ }^{2}\left(40-80 \mathrm{Ku} / \mathrm{Kм}^{2}\right)$} \\
\hline 10,36 & 14,34 & 24,62 & 2,86 & 1,26 & 1,60 & 21,76 \\
\hline \multicolumn{7}{|c|}{ 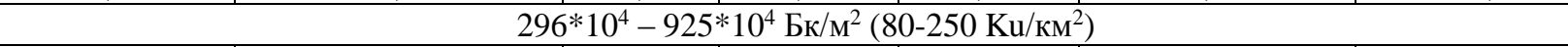 } \\
\hline 8,05 & 14,86 & 24,78 & 3,40 & 2,01 & 1,39 & 21,38 \\
\hline
\end{tabular}


Данные таблицы 2 позволяют считать, что митотический индекс с увеличением радиации на первом этапе повышается на $0,8 \%$, а с дальнейшим усилением радиационного фактора понижается на 2,3 \%. Продолжительность анафазы выше в контроле на 0,71-1,2 \%.

Количество анафаз с нарушениями выше в проростках семян ели из радиационно загрязненных ельников и остается на одном уровне при дальнейшем повышении радиационного фактора.

Общее число хромосомных аберраций возрастает с увеличением радиации на $0,6-1,2 \%$. В контроле и на уровне $40-80 \mathrm{Ku} / \mathrm{Kм}^{2}$ преобладают фрагменты, а при дальнейшем повышении радиации на первый план выходят мосты 2,01 \%.

Общий фон на количество анафаз с нарушениями создают выходы и отставания хромосом 14,3-21,76 \%, причем этот уровень достигается сразу и остается почти неизменным.

Частота хромосомных аберраций проростков желудей дуба черешчатого

\begin{tabular}{|c|c|c|c|c|c|c|}
\hline \multirow{4}{*}{$\begin{array}{c}\text { Митотический } \\
\text { индекс, \% }\end{array}$} & \multirow{4}{*}{$\begin{array}{c}\text { Продолжительность } \\
\text { анафазы, \% }\end{array}$} & \multicolumn{5}{|c|}{ Количество анафаз с нарушениями, \% } \\
\hline & & \multirow{3}{*}{ Всего } & \multicolumn{3}{|c|}{ Хромосомные аберрации } & \multirow{3}{*}{$\begin{array}{l}\text { Выходы и } \\
\text { отставания } \\
\text { хромосом }\end{array}$} \\
\hline & & & \multirow{2}{*}{$\begin{array}{l}\text { Общее } \\
\text { число }\end{array}$} & \multicolumn{2}{|c|}{ В том числе } & \\
\hline & & & & Мосты & Фрагменты & \\
\hline \multicolumn{7}{|c|}{ КОНТРОЛЬ } \\
\hline 4,23 & 23,46 & 2,16 & 1,82 & 0,91 & 0,91 & 1,24 \\
\hline \multicolumn{7}{|c|}{$148 * 10^{4}-296 * 10^{4}$ Бк/ $/ \mathrm{m}^{2}\left(40-80 \mathrm{Ku} / \mathrm{KM}^{2}\right)$} \\
\hline 4,03 & 25,08 & 2,39 & 1,62 & 0,95 & 0,67 & 1,22 \\
\hline \multicolumn{7}{|c|}{ 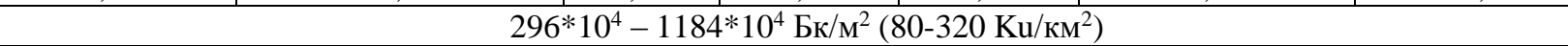 } \\
\hline 4,01 & 26,34 & 4,49 & 2,72 & 1,16 & 1,56 & 1,77 \\
\hline
\end{tabular}

Митотический индекс у проростков желудей дуба черешчатого не зависит от радиационного фактора, так как изменяется в очень узких пределах 4,01-4,23 \%. Продолжительность анафазы несколько увеличивается на 1,62-2,88 \%. Такими же темпами возрастает количество анафаз с нарушениями по сравнению с контролем на 0,23-2,33 \%.

Общее число хромосомных аберраций в начальный период радиационного воздействия незначительно на 0,2 \% снижается, а затем при повышении радиации возрастает по отношению к контролю на $0,9 \%$. В контроле количество мостов и фрагментов равное количество 0,91\%, при действии радиации количество мостов остается практически на одном уровне, а число фрагментов снижается на 2,4 \%. При дальнейшем повышении радиационного фактора увеличивается количество мостов и фрагментов соответственно до 1,16 \% и 1,56 \%. Следует отметить, что в проростках семян дуба черешчатого наблюдается очень низкий процент выхода и отставания хромосом, всего 1,22-1,77\%.

Анализируя данные хромосомных аберраций по трем древесным видам (таблицы 1-3), следует отметить, что у хвойных видов митотический индекс в 2 и более раза выше, чем у дуба черешчатого. Так у сосны обыкновенной он изменяется от $8,52 \%$ до 9,73\%, а у ели европейской от $8,05 \%$ до 10,36 \%. При этом у сосны митотический индекс снижается на $1,2 \%$, у ели на первом этапе действия радиации повышается на 0,8 \%, а затем при повышении радиации снижается на $2,3 \%$.

Продолжительность анафазы у хвойных пород ниже, чем у дуба черешчатого. У сосны она изменяется в пределах 17,22 \% - 18,76 \%, у ели в пределах $14,34 \%-15,57 \%$. Радиационный фактор способствует увеличению продолжительности анафазы у сосны в пределах 1,5 \%, а у ели изменяется так же с небольшим возрастанием признака $(0,5$ \%) на конечном этапе. 
Продолжительность анафазы у дуба черешчатого выше, чем у хвойных видов и составляет 23,46 \% - 26,34 \%. Радиационный фактор способствует увеличению признака на $2,88 \%$.

Анализ анафаз с нарушениями позволяет отнести хвойные растения к наиболее радиочувствительным древесным видам. В проростках семян сосны анафазы с нарушениями в контроле составляют 14,88 \%, а при действии радиационного фактора повышается на 17,2 \% и у ели в контроле составляет 16,55 \% затем повышаются на 8,23 \%.

В проростках желудей дуба черешчатого этот показатель намного ниже и в контроле равен 2,16 \%, а с действием радиационного фактора повышается всего на 2,33 \%.

Рост количества анафаз с нарушениями происходит у хвойных видов в основном за счет выхода и отставания хромосом. Данный показатель у сосны в контроле составляет 12,7 \% и у ели 14,3 \%, при воздействии радиации показатель возрастает соответственно на 16,38 \% у сосны, и на $7,46 \%$ у ели.

Количество именно хромосомных аберраций у всех исследуемых древесных видов распределяется так: в контроле у сосны $2,18 \%$, у ели $2,25 \%$ и у дуба $1,82 \%$. Под действием радиационного фактора происходит увеличение числа хромосомных аберраций у сосны на $0,81 \%$, у ели на $1,15 \%$ и у дуба на $0,9 \%$.

Из хромосомных аберраций наиболее часто встречаются фрагменты и максимально достигают у сосны $2,23 \%$, у ели $1,60 \%$ и у дуба $1,56 \%$; мосты у сосны не превышают значения $0,78 \%$, у дуба находится на уровне $1,16 \%$ и только у ели доходит до $2,01 \%$.

Анализируя сравнительные данные по трем древесным породам следует сделать следующий вывод, что к наиболее радиоустойчивому виду относится дуб черешчатый, хвойные виды более радиочувствительные и отдать предпочтение одному из них не представляется возможным. По ряду показателей (мосты) это ель европейская, а по таким показателям как количество анафаз с нарушениями, выходы и отставания хромосом - сосна обыкновенная.

Цитологические исследования семенного потомства фенотипически нормального дерева сосны обыкновенной, произрастающего при близком к нормальному радиационном фоне, но вблизи Новозыбковской автодороги в Брянской области, по которой следует транспорт в зону ЧАЭС и обратно, наблюдались ранее неизвестные у сосны цитологические аномалии. В ряде клеток происходила замена митотического деления на амитоз и, наряду с этим, другие нарушения, такие как микроядра, сложные мосты и фрагменты в анафазе (рисунок 1).
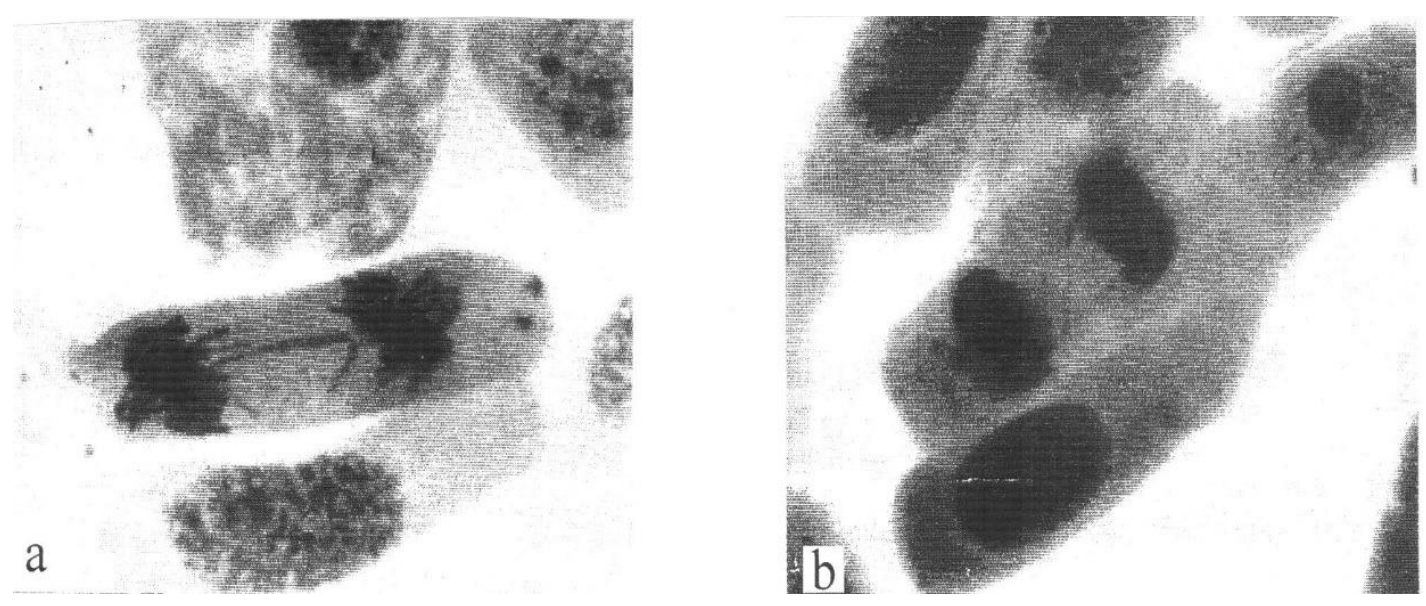

Рисунок 1. Хромосомные мостики: (а) с фрагментами, (b) без фрагментов в анафазе сосны 
Поскольку у потомства деревьев сосны из того же насаждения, произрастающих даже при более высоких уровнях загрязнения, но дальше от автодороги, таких нарушений в процессе деления клеток не наблюдалось, следует рассматривать их как влияние синергизма физических и химических факторов.

Амитоз у сосны - неизвестное ранее и необычное для данного вида цитологическое явление. Ядра таких клеток делятся на две неравные части путем фрагментации без цитокинеза или при неполном цитокинезе, сопровождаемом фрагментацией одного из дочерних ядер (рисунок 2).
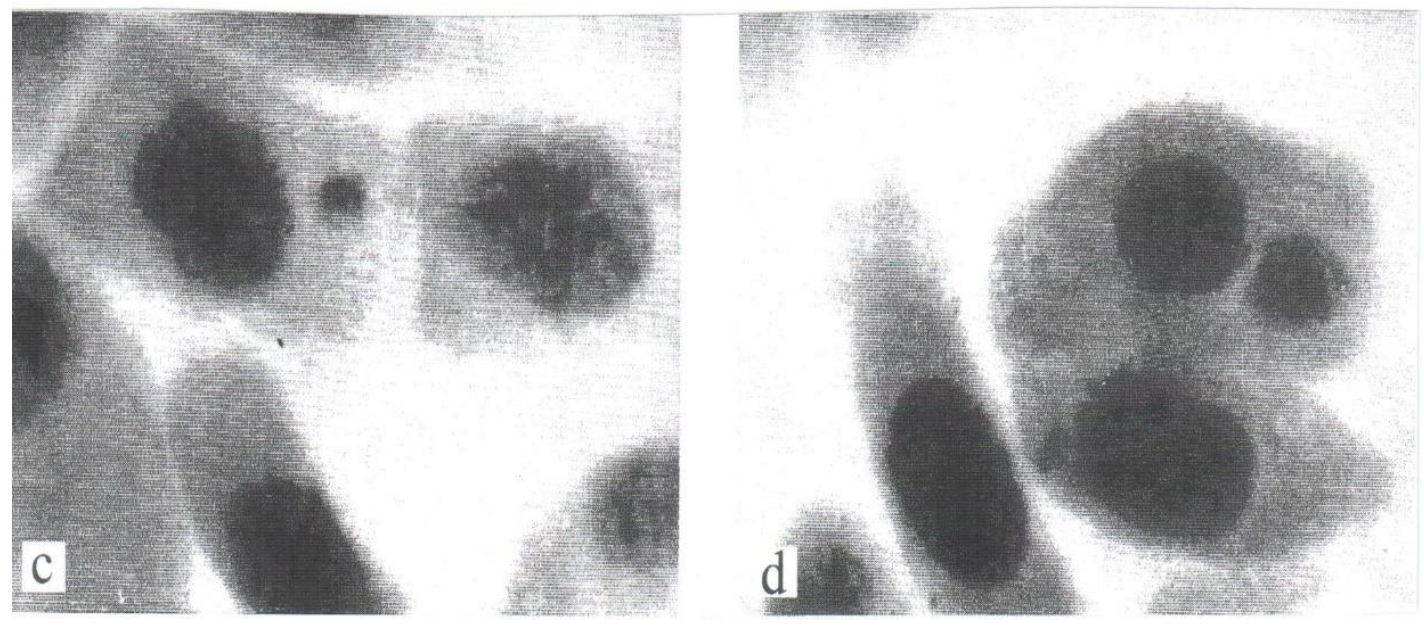

Рисунок 2. c, $d$-Клетки с микроядрами возникшими из-за амитоза

Хорошо известно, что амитоз в норме характерен только для дегенерирующих тканей. Следовательно, замена митоза на амитоз в некоторых меристематических клетках у проростков сосны может рассматриваться как следствие развития у них патологических процессов. Такие процессы могут быть индуцированы радиацией, поскольку Брянская область сильно пострадала вследствие Чернобыльской аварии. Материнское дерево также хронически подвергается воздействию химических выбросов, так как оно произрастает вблизи Новозыбковской автодороги. По-видимому, амитоз является влиянием на клеточном уровне синергических эффектов двух этих факторов среды, физического и химического.

Нами изучались отдаленные последствия воздействия радиации на потомство деревьев дуба черешчатого, произрастающих в насаждениях вдоль автодороги. В интерфазных ядрах проростков дуба, выращенных из желудей, собранных вдоль автодороги, как правило, наблюдалось два ядрышка. Многоядрышковость у дуба в данном случае можно рассматривать как цитологические проявления реакции, приводящей к образованию белков теплового шока при активации рДНК, и подавление действия ряда структурных генов радиацией. Совместное воздействие слабых доз радиации и различного рода поллютантов (в данном случае выхлопных газов машин) могут привести к синергическим эффектам по силе равным острому облучению.

\section{Заключение}

Проведенные исследования хромосомных аберраций методом давленных препаратов проростков семян сосны обыкновенной, ели европейской и желудей дуба черешчатого позволяют считать, что все исследуемые виды увеличивают частоту хромосомных аберраций.

Наиболее радиочувствительными оказались хвойные виды древесных растений, дуб черешчатый следует отнести к наиболее радиоустойчивому виду. 
При создании придорожных насаждений не следует использовать посадочный материал, полученный из семян хвойных растений и желудей дуба черешчатого произрастающих в радиационно загрязненных зонах вблизи автомобильных магистралей.

Следует отметить, что семена, полученные в радиационно-загрязненных насаждениях вдали от автодорог, дают нормальные всходы. Нашими исследованиями установлено, что в конце вегетационного периода сохранность сеянцев сосны обыкновенной, ели европейской и дуба черешчатого составила 70,9-80,4 \%.

При этом показатели сохранности и ростовых процессов не существенно отличались от показателей сеянцев, выращенных из семян, собранных в относительно чистых насаждениях.

Из этого следует, что исследованные древесные виды и тем более кустарники можно без ограничения использовать при создании придорожных ландшафтов, но семена следует заготавливать вдали от автомагистрали.

\section{ЛИТЕРАТУРА}

1. Алексахин Р.М. Радиоэкологические уроки чернобыля // Радиобиология. - 1993. - Т.33, вып.1. - С. 3-14.

2. Буторина А.К., Плетминцева Т.И., Веткасов В.Н. Цитологическая характеристика плюсовых деревьев дуба черешчатого из Шипова леса // Доклады АН СССР, 1986. - T.289. - №5. - C. 1241-1244.

3. $\quad$ Гродзинский Д.М. Радиобиология растений. - Киев: Наукова думка, 1989. - 282 с.

4. Действие гамма-излучения на вегетативные и репродуктивные органы сосны Pinus sylvestris / И.С. Федотов, Ф.А. Тихомиров, Р.Т. Карабань, Б.С. Пристер. М.: Гидрометиздат, 1979. - Тр. Ин-та прикладной геофизики, вып. 38. - С. 53-67.

5. Действие острого гамма-облучения на лесной биогеоценоз / Р.Т. Карабань, Н.Н. Мишенков, Б.С. Пристер, Р.М. Алексахин, Ф.А. Тихомиров, Е.А. Федоров, Г.Н. Романов. - М.: Гидрометиздат, 1979. - Труды ИПГ, вып. 38 - С. 27-52.

6. Иванов В.Б. Клеточные основы роста растений. - М., 1974. - 223 с.

7. Исследования репродуктивной сферы сосны обыкновенной в районе аварии на Чернобыльской АЭС / Козубов Г.М., Банников В.П., Таскаев А.И., Артемова В.А., Остапенко Е.К., Сытник К.М. - Киев, 1988. - 78 с.

8. Кальченко В.А., Рубанович А.В., Федотов И.С., Архипов Н.П. Генетические эффекты, индуцированные Чернобыльской аварией, в половых клетках сосны обыкновенной (Pinus sylvestris L.) // Генетика. - 1993. - Т. 29, № 7 - С. 1205-1212.

9. Кальченко В.А., Спирин Д.А. Генетические эффекты в популяциях сосны обыкновенной, произрастающих в условиях хронического облучения малыми дозами // Радиобиология. - 1989. Т. 25, №6. - С. 1059-1064.

10. Карабань Р.Т., Тихомиров Ф.А. Радиобиологические действия 90Sr и 137Cs на сеянцы сосны, ели и лиственницы / Р.Т. Карабань, Ф.А. Тихомиров // Лесоведение - 1968, №92. - c. 91-94.

11. Кудинов М.А. Внешняя среда и формирование устойчивости у древесных растений. - Минск: Наука и техника, 1986. - 167 с. 
12. Кузин А.М. Стимулирующее действие ионизирующего излучения на биологические процессы. - М.: Атомиздат, 1977. - 133 с.

13. Методика кариологического изучения хвойных / Л.Ф. Правдин, В.А. Бударагин, М.В. Круклис, О.П. Шершукова // Лесоведение. - 1972. - №2. - С. 67-76.

14. Пойкер Х. Культурный ландшафт: формирование и уход / Пер. с нем. В.В. Цветкова // Х. Пойкер. - М.: Агропромиздат, 1987. - 176 с.

15. Преображенская Е.И. Радиоустойчивость семян растений // Е.И. Преображенская. - М.: Агропромиздат, 1971. - 231 с.

16. Преображенская Е.И. Радиоустойчивость семян в свете закона гомологических рядов в наследственной изменчивости // Докл. АН СССР. - 1973. - 209. №6. - С. $1470-1472$.

17. Робертис Э., Новинский В., Саэс Ф. Биология клетки / Пер. с англ. - М.: Мир., 1967. -222 c.

18. Самошкин Е.Н. Воздействие химических мутагенов на древесные растения. - М.: Лесн. Пром-сть, 1980. -88 с.

19. Сидоров В.П. Продленный мутагенез и морфогенез у растений при действии радиации, алкилирующих мутагенов и гербицидов: Дисс. В форме науч. Докл....ра биол. Наук. - М., 1992. - 53 с.

20. Сидоров В.П. Цитогенетический эффект в клетках хвои сосны обыкновенной при облучении в результате аварии на Чернобыльской АЭС // Радиационная биология. Радиоэкология. - 1994. Т.34. - Вып.6. - С. 847-851.

21. Сидоров В.П., Тихомиров Ф.А. Биологические эффекты облучения сосны обыкновенной в зоне аварии на Чернобыльской АЭС // Тез. Докл.1 Всесоюз. радиобиол. съезда. - Москва; Пушкино, 1989. - Т.2. - С. 530-531.

22. Тихомиров Ф.А. Влияние ионизирующих излучений на репродуктивную способность древесных растений // Лесоведение. - 1973. - №3. - С. 65-76.

23. Хвостова В.В., Невзгодина Л.В. Связь радиочувствительности с химическим составом // Радиобиология. - 1960, №2, 4. - С. 31-35.

24. Хотылева Л.В., Дыленок Л.А., Яцевич А.П., Гончаренко Г.Г. Влияние повышенного радиационного фона на частоту хромосомных аберраций у ели европейской (Picea abies (L) Karst) // Докл. АН Беларуси. - 1992. - Вып. 36, № 910. - C. 842-845.

25. Butorina A.K., Evstratov N.P. The first detected case of amitosis in pine // A.K. Butorina, N.P. Evstratov Forest genetics. 1996. - vol.3, №3. - P. 145-148. 
Evstratov Nikolai Petrovich

Bryansk state engineering-technological university, Bryansk, Russia

E-mail: evstratov.bryansk@gmail.com

\section{Especially in the creation of roadside plantations}

Abstract. Roads should fit into the landscape in such a way that their negative impact on the appearance and condition of the natural landscape is minimal. Such interference in nature leads to the dismemberment of forests, disruption of the natural movement of groundwater, runoff of surface waters, destruction of habitats and cut-off of animal migration routes, climate degradation.

It is unlikely to be possible to eliminate the negative effects completely, due to the choice of the route, taking into account the conditions of the terrain and with the help of appropriate design, the road can sometimes fit into the landscape and, perhaps, even improve its appearance. In addition, during road construction it is possible to create interesting and valuable habitats of animals and plants, thus increasing the biodiversity of roadside landscapes.

The laying of roadside landscapes goes far beyond the usual border of the road rows of plantations. Proper placement of roadside vegetation of lawns, trees and shrubs, provides a significant reduction in the cost of care and maintenance in the order of the roadbed.

It is known that operation of highways leads to techno genic pollution of adjacent territories together with roadside plantings. In addition, highways can pass through the territory contaminated with radionuclides. In this case, the phenomenon of synergism often occurs when man-made pollution is summed up with the radiation factor. At the same time, the combined effect of two factors on biological objects increases significantly.

Keywords: landscape; pollution; radionuclides; pollutants; synergism; nucleus; cytokines; anaphase; bridges; fragments; chromosomes; mitosis; amitosis; meristem; gene; gray; Becquerel; rDNK

\section{REFERENCES}

1. Aleksakhin R.M. (1993). Radioecological lessons of Chernobyl. Radiobiology, 1(33), pp. 3-14. (in Russian).

2. Butorina A.K., Pletmintseva T.I., Vetkasov V.N. (1986). Cytological characterization of plus trees of pedunculated oak forests of Shipova. Doklady AN SSSR, 5(289), pp. 1241-1244. (in Russian).

3. Grodzinsky D.M. (1989). Radiobiologija rastenij. [Radiobiology of plants.] Kiev: Naukova Dumka, p. 282.

4. Fedotov I.S., Tikhomirov F.A., Karaban R.T., Prister B.S. (1979). Effect of gamma radiation on vegetative and reproductive organs of pine Pinus sylvestris. Tr. Institute of applied Geophysics, iss. 38, pp. 53-67. (in Russian).

5. Karaban R.T., Mishenkov N.N., Prister B.S., Aleksakhin R.M., Tikhomirov F.A., Fedorov E.A., Romanov G.N. (1979). Effect of acute gamma irradiation on a forest biogeocenosis. The IPG works, 38, pp. 27-52. (in Russian).

6. Ivanov V.B. (1974). Kletochnye osnovy rosta rastenij. [Cellular basis of plant growth.] Moscow, p. 223.

7. Kozubov G.M., Bannikov V.P., Taskaev A.I., Artemov V.A., Ostapenko E.K., Sytnik K.M. (1988). Issledovanija reproduktivnoj sfery sosny obyknovennoj v rajone avarii na Chernobyl'skoj A`ES. [Studies of the reproductive sphere of Scotch pine in the area of the accident at the Chernobyl nuclear power plant.] Kiev, p. 78. 
8. Kalchenko V.A., Rubanovich A.V., Fedotov I.S., Arkhipov N.P. (1993). Genetic effects induced by the Chernobyl accident in the sex cells of an ordinary pine (Pinus sylvestris L.). Genetica, 7(29), pp. 1205-1212. (in Russian).

9. Kalchenko V.A., Spirin D.A. (1989). Genetic effects in populations of Scots pine growing in conditions of chronic irradiation in small doses. Radiobiology, 6(25), pp. 1059-1064. (in Russian).

10. Karaban R.T., Tikhomirov F.A. (1968). Radiobiological actions 90Sr and 137Cs on seedlings of pine, spruce and larch. Lesovedenie, 92, pp. 91-94. (in Russian).

11. Kudinov M.A. (1986). Vneshnjaja sreda i formirovanie ustojchivosti u drevesnyh rastenij. [External environment and the formation of resistance in woody plants.] Minsk: Science and technology, p. 167.

12. Kuzin A.M. (1977). Stimulirujuschee dejstvie ionizirujuschego izluchenija na biologicheskie protsessy. [The stimulating action of ionizing radiation on biological processes.] Moscow: Atomizdat, p. 133.

13. Pravdin L.F., Budaragin V.A., Kruklis M.V., Shershukova O.P. (1972). Methods karyological study of coniferous. Lesovedenie, 2, pp. 67-76. (in Russian).

14. Poiker H. (1987). Cultural landscape: formation and care. [Russ. ed.: Kul'turnyj landshaft: formirovanie i uhod. Authorized transl. by V.V. Tsvetkova. Moscow: Agropromizdat, p. 176].

15. Preobrazhenskaya E.I. (1971). Radioustojchivost' semjan rastenij. [Radio Resistance of plant seeds.] Moscow: Agropromizdat, p. 231.

16. Preobrazhenskaya E.I. (1973). The radioresistance of seeds in the light of the law of homological rows in hereditary variability. Dokl. USSR ACADEMY OF SCIENCES, 6, pp. 1470-1472. (in Russian).

17. Robertis E., Novinsky V., Saes F. (1967). Biologija kletki. [Cell Biology.]. Moscow: World, p. 222.

18. Samoshkin E.N. (1980). Vozdejstvie himicheskih mutagenov na drevesnye rastenija. [Effects of chemical mutagens on woody plants.] Moscow: Lesn. Prom., p. 88.

19. Sidorov V.P. (1992). Prodlennyj mutagenez i morfogenez u rastenij pri dejstvii radiatsii, alkilirujuschih mutagenov i gerbitsidov. [Prolonged mutagenesis and morphogenesis in plants under the influence of radiation, alkylating mutagens and herbicides.] Moscow, p. 53.

20. Sidorov V.P. (1994). Cytogenetic effect in the cells of the needles of Scots pine during irradiation as a result of the Chernobyl accident. Radiation biology. Radioecology, 6(34), pp. 847-851. (in Russian).

21. Sidorov V.P., Tikhomirov F.A. (1989). Biological effects of irradiation of Scots pine in the area of the accident at the Chernobyl nuclear power plant. Tez. Dokl.1 all-Union. radiobiol. Congress's, 2, pp. 530-531. (in Russian).

22. Tikhomirov F.A. (1973). Influence of ionizing radiation on the reproductive capacity of woody plants. Lesovedenie, 3, pp. 65-76. (in Russian).

23. Khvostova V.V., Nevzgodina L.V. (1960). The relationship of radiosensitivity with the chemical composition. Radiobiology, 2(4), pp. 31-35. (in Russian).

24. Khotyleva L.V., Dylenok L.A., Yatsevich A.P., Goncharenko G.G. (1992). Influence of elevated radiation background on the frequency of chromosomal aberrations in European spruce (Picea abies (L/) Karst). Dokl. Academy of Sciences of Belarus, 910(36), pp. 842-845. (in Russian).

25. Butorina A.K., Evstratov N.P. (1996). The first detected case of amitosis in pine. Forest genetics, 3(3), pp. 145-148. 